\title{
Turizm Rehberliği Bölümü Öğrencilerinde Genel Öz Yeterlilik Algısı, Mesleki Kaygı ve Mesleği Yapma Niyeti İlişkisi*
}

The Relationship Between General Self-Efficacy, Occupational Anxiety and Intention to Perform the Profession of Tourism Guiding Students

\author{
Burhan ÇINAR**, Uysal YENIPINAR*** \\ **Arş. Gör., Mersin Üniversitesi Turizm Fakültesi Çiftlikköy Kampüsü, 33343 Yenişehir, Mersin. \\ E-posta: burhancinar@mersin.edu.tr \\ ORCID: 0000-0002-0778-4050 \\ ***Doç. Dr., Mersin Üniversitesi Turizm Fakültesi Çiftlikköy Kampüsü, 33343 Yenişehir, Mersin. \\ E-posta: uysalyenipinar@mersin.edu.tr \\ ORCID: 0000-0002-6357-8729
}

\section{MAKALE BILGILERI}

Makale işlem bilgileri:

Gönderilme tarihi: 25 Aralık 2018

Düzeltme: 1 Mart 2019

Düzeltme: 29 Mart 2019

Kabul: 22 Nisan 2019

Anahtar sözcükler: Öz-yeterlilik, Mesleki kaygı, Mesleği yapma niyeti, Turist rehberliğ $i$.

\section{ARTICLE INFO}

Article history:

Submitted: 25 December 2018

Resubmitted: 1 March 2019

Resubmitted: 29 March 2019

Accepted: 22 April 2019

Key words: Self-efficacy, Occupational anxiety, Intention to perform the profession, Tourist guiding. öz

This paper examines the relationship between the general self-efficacy, occupational anxiety and the intention to perform the profession of the prospective tourist guides. The data are collected by convenience sampling technique from the prospective tourist guides who are studying in the tourism guiding departments. Descriptive factor analysis and correlation analysis are used in descriptive statistical techniques. Factor analysis shows that prospective tour guides' occupational anxieties are grouped under eight dimensions and their intentions to perform the proffesion are grouped under two dimensions. Correlation analysis confirms a negative relationship between self-efficacy and occupational anxiety, a positive relationship between self-efficacy and intetion to perform the profession and a negative relationship between anxiety and intention to perform the profession. Considering the higher relationship of self-efficacy with the intention to perform the profession than ocupational anxiety, the fact that educational institutions bring together prospective tourist guides with the professional guides will enable them to prepare better for the profession.

\begin{abstract}
Bu çalışmada turist rehberi adaylarının algıladıkları genel öz-yeterlilik, mesleki kaygı ve mesleği yapma niyetleri arasındaki ilişki incelenmektedir. Veriler kolayda örnekleme tekniğine göre turizm rehberliği bölümlerinde öğrenim gören turist rehberi adaylarından anket aracılığıyla toplanmıștır. Verilerin analizinde açıklayıcı faktör analizi ve korelasyon analizinden yararlanılmıştır. Faktör analizi neticesinde turist rehberi adaylarının mesleki kaygılarının sekiz boyut altında, mesleği yapma niyetlerinin iki boyut altında toplandığı tespit edilmiştir. Korelasyon analizi sonuçları, öz-yeterlilik ile mesleki kaygı arasında ters yönlü ve orta düzeyde bir ilişki, öz-yeterlilik ile mesleği yapma niyeti arasında ise pozitif yönlü ve orta düzeyde bir ilișki ve mesleki kaygı ile mesleği yapma niyeti arasında ters yönlü ve zayıf bir ilişki olduğunu göstermektedir. Öz-yeterliliğin, mesleki kaygıdan daha yüksek düzeyde mesleği yapma niyeti ile olan ilișkisi göz önüne alındığında eğitim kurumlarının turist rehberi adaylarını meslek profesyonelleri ile daha fazla bir araya getirmesi onların mesleğe daha iyi hazırlanmasını sağlayacaktır.
\end{abstract}

\section{GiRiş}

Turist rehberleri, turizm endüstrisi içerisinde destinasyona gelen ziyaretçilerle en fazla etkileşim içinde bulunan meslek mensuplarıdır (De-

*Bu makale, Burhan Çınar'ın Mersin Üniversitesi Sosyal Bilimler Enstitüsü'nde yazılan “Turizm Rehberliği Bölümü Öğrencilerinde Genel Öz yeterlilik Alg1sı, Mesleki Kayg1 ve Mesleği Yapma Niyeti İlişkisi" başlıklı yüksek lisans tezinden derlenmiştir. ğirmencioğlu 2001) ve turist rehberliği turizm sektörü içindeki kilit mesleklerden biridir. Bu bağlamda, mesleği yürütecek bireyin karakter özelliklerinin, bilgi, beceri ve teknik olarak geniş kapsamlı nitelikleri barındırması gerekir (Tetik 2006). Dolayısıyla bir turist rehberinin, çok farklı rolleri yürütmesi, yabancı dil bilmesi, kendi ülkesinin tarihi ve kültürünün yanı sıra farklı ülkelerin kültürlerini iyi tanıyıp, kültürlerarası ileti- 
şim yeterliliğinin güçlü olması, grup psikolojisi ve söz söyleme sanatı gibi farklı disiplinlerarası konulara hâkim olması beklenir (Weiler ve Black 2015). Bunlar, turist rehberinin sonradan, özellikle eğitim ile edinilebildiği beceri ve niteliklerdir. Eğitimden önce de bireyin turist rehberliği mesleğine ilgi duyması, seyahat etmeyi, tarihi, doğayı, insanları, konuşmayı, anlatmayı ve okumayı seviyor olması gibi içsel faktörler gerekmektedir.

Turist rehberliği gerektirdiği roller, nitelikler ve beceriler dışında çeşitli sorunları, zorlukları ve sorumlulukları da barındıran bir meslektir (Ahipaşaoğlu 2006). Turist rehberliği, turizm sektörünün kriz, terör, siyasi istikrarsızlık, mevsimlik iş imkânı gibi özelliklerinden de etkilenmektedir. Mesleğin sahip olduğu bu özelliklerin turist rehberi adaylarını psikolojik olarak nasıl etkilediğine yönelik olarak alanyazında herhangi bir çalışmaya rastlanmamıştır. Bu araştırmada, "turist rehberliği mesleği" ile "mesleki kayg1" ilişkilendirilerek alanyazına katkı sunulmaya çalışılmıştır. Bu nedenle çalışmanın temel amacı turist rehberi adaylarının genel öz yeterlilik alg1ları, mesleki kaygı düzeyleri ve mesleği yapma niyetleri arasındaki ilişkinin belirlenmesidir. Çalışmanın ikincil amacı ise turist rehberliği öğrencilerinin mesleki kaygılarını ölçen, geçerliliği ve güvenirliği test edilmiş bir ölçek tasarlamaktır. Elde edilecek sonuçlar bağlamında rehber adaylarının ne tür mesleki kaygılar taşıdığı, bunların öz-yeterlilik algısı ve mesleği yapma niyeti ile ilişkileri bağlamında turist rehberliği eğitimine ve mesleğin pratik alanına yönelik öneriler sunulması planlanmaktadır.

\section{KAVRAMSAL ÇERÇEVE VE ALANYAZIN}

\section{Öz-Yeterlilik}

Öz-yeterlilik, bireylerin yaşamlarını etkileyen olayları yönetme yetenekleri hakkındaki inançları olarak tanımlanır. Öz-yeterlilik, bireylerin, kendilerini nasıl hissettiklerini, nasıl düşündüklerini, nasıl motive olduklarını ve davranışlarını belirler (Bandura 1994). Öz-yeterlilik bir işi, eylemi veya görevi başarmak için verilen çabayı, olumsuzluklara karşı pes etmemeyi ve 1srarlı olmayı betimlemektedir (Aşkar ve Umay 2001).
Öz-yeterlilik algıları hem davranışları hem de duyguları etkilemektedir. Bu özellikle bilinmeyen ve potansiyel olarak caydırıcı olaylara verilen stres ve kaygı tepkileri bağlamında doğrudur. Öz-yeterlilik teorisinin temellendiği sosyal öğrenme perspektifine göre, potansiyel olarak caydırıcı ve engelleyici olayları korku ve kayg1 kaynağı yapan temel olarak algılanan özyetersizliktir (Bandura 1982). Bireyler kendi düşüncelerini değiştirme yeteneğine sahiptirler, buna karşıllk olarak da öz-yeterlilik inançları fizyolojik durumlarını etkiler. Yeterlilik kavramı ile fizyolojik ve psikolojik göstergeler arasında iki yönlü bir ilişki vardır. Bu fizyolojik ve psikolojik göstergelerden biri de kaygı olarak ortaya çıkmaktadır (Pajares ve Miller 1994). Bu iki yönlü ilişki olumsuzdur (Kafkas vd. 2010). Kavramsal arka plan ve alanyazındaki çalışmalardan hareketle $\mathrm{H} 1$ geliştirilmiştir.

\section{H1: Öz-yeterlilik ile kaygı arasında ters yönlü bir ilişki vardır.}

Öz-yeterlilik mesleki gelişim ve kariyer süreçlerinde de etkili olan bir etmendir (Betz ve Hackett 1981) ve mesleki değerden çok daha yüksek bir oranla meslek tercihi ile ilişkilidir (Wheeler 1983). Örneğin; öz-yeterlilik inancı toplumsal cinsiyet kalıplarına uygun görülmeyen mesleklere yönelik niyeti etkilemektedir (Nevill ve Schlecker 1988). Benzer şekilde öz-yeterlilik bir meslekte algilanan engellerle beraber bir mesleği yapma niyetini etkileyebilmektedir (Everhart ve Chelladurai 1998). Buna ek olarak, kariyerleri hakkında daha yüksek karar verme öz-yeterliliğine sahip bireyler, kariyerlerine daha fazla bağlı kalmaktadırlar (Chesnut ve Burley 2015) ve öz-yeterlilik bir meslekte maaş, statü ve kariyer memnuniyeti üzerinde olumlu bir etki yaratmaktadır (Abele ve Spurk 2009). Ayrıca öz-yeterlilik bir iş başvurusunda hissedilen kaygı düzeyini de etkileyen ve bireyin daha yüksek öznel iyi oluşunu etkileyen bir etmendir (Deer, Gohn ve Kanaya 2018). Kavramsal arka plan ve alanyazındaki çalışmalardan hareketle $\mathrm{H} 2$ geliştirilmiştir.

$\mathrm{H}_{2}$ : Öz-yeterlilik ve mesleği yapma niyeti arasında pozitif yönlü bir ilişki vardır. 


\section{Kayg।}

Kaygı, bireyin varoluşu için gerekli gördüğü bir değeri tehdit ederek ortaya çıkan endişedir. Tehdit fiziksel, psikolojik veya bireyin kendi varoluşuyla özdeşleştirdiği diğer başka değerlere yönelik olabilir (May 1950). Kayg1, hemen hemen tüm çağdaş kişilik kuramlarında merkezi bir açıklayıcı kavram olarak bulunur ve zayıflatıcı psikolojik ve psikosomatik belirtiler gibi çeşitli davranışsal sonuçları olan nedensel etmen olarak görülür (Spielberger 1966). Kaygının birey davranışları üzerinde etkileri; bireyin psikolojik durumuna, yetkinliğine ve bireyin içerisinde bulunduğu duruma göre engelleyici ve güdüleyici etkileri olabilmektedir. Eğer bireyin içerisinde bulunduğu durum, bu bir tür görev veya eylem olabilir, kendi kabiliyet düzeyini aşan bir derecedeyse bireyin algıladığı başaramama duygusu davranışları üzerinde kaygının engelleyici etkisini yaratmaktadır (Scovel 1978).

Kaygı, çalışma ortamındaki yüksek gerginlik ile ilişkilidir ve kaygı ile iş performansı arasında anlamlı bir ilişkiye rastlanmaktadır (Kenny, Davis ve Oates 2004). Kaygi, bireyi meslek ve kariyer alanında da etkilemektedir. Kaygı düzeyinin yükselmesi öncellikle bireyin geleceği hakkında ne yapacağını bilmemesine ve kararsızlık yaşamasına neden olmaktadır (Çakmak ve Hevedanlı 2005). Bu kararsızlık ve belirsizlik bireyin meslek eğitiminden sonraki kaygı düzeyini artırmakta (Ergin, Uzun ve Topaloğlu 2016) ve bireylerin mesleğe yönelik olumsuz tutum geliştirmelerine neden olmaktadır (Serin, Güneş ve Değirmenci 2015). Ayrıca bireylerin kariyer kararlılıklarına ve kariyer kararı memnuniyetlerine olumsuz etkide bulunmaktadır (Kimes ve Troth 1974). Kavramsal arka plan ve alanyazındaki çalışmalardan hareketle $\mathrm{H} 3$ geliştirilmiştir.

\section{$H_{3}:$ Kaygı ve mesleği yapma niyeti arasında ters yönlü anlamlı bir ilişki vardır.}

Turist rehberliği alanyazını incelendiğinde, mesleğin sahip olduğu özelliklerin rehber adayında çeşitli kaygılar yaratabileceği ve mesleği yapma niyetini olumsuz etkileyebileceği söylenebilir. Özellikle mesleğin yıl boyunca yap1lamaması, iş garantisinin olmayışı (Yazıcıoğlu,
Tokmak ve Uzun 2008), yeni mezun olmuş turist rehberlerine düşük ücret ödenmesi, geçim sağlamak için yeterli ve sabit bir gelirinin olmaması (Güzel, Türker ve Şahin 2014), güvencesizlik ve emeklilik hakkının geç elde edilmesi (Ahipaşaoğlu 2006) başta gelen faktörlerdir. Turist rehberliği, evlilik ve meslek ilişkisinde biri dizi olumsuz tutum oluşturabilmekte (Doğan, Üngüren ve Kesgin 2010), uzun çalışma saatleri aile ilişkilerini olumsuz etkileyebilmekte (İrigüler ve Güler 2016) ve iş-aile dengesinin kurulmasını zorlaştırabilmektedir (Yazıcıoğlu, Tokmak ve Uzun 2008). Ayrica seyahat acentaları tarafindan ciddiye alınmama, komisyonculuğa zorlanma, sosyal hakların yetersizliği, kaçak turist rehberliği, taban yevmiyenin altında çalışılması (Köroğlu vd. 2007; Yazıcı̆̆lu Tokmak ve Uzun 2008) mesleğin diğer önemli sorunlarıdır. Nitekim Yetgin (2017) tarafından yapılan çalışmada turist rehberlerinin ekonomik kaygılarının tükenmişlik düzeylerini artırdığ 1 tespit edilmiştir.

Diğer bir yandan turist rehberinin taşıması beklenen, topluluk önünde konuşabilme ve topluluğa hitap edebilme (Değirmenci 2003), iletişim becerisi, insanları anlama ve hoş görme, dişa dönük sosyal olma, esprili olma, soğukkanlı ve dayanıklı olma (Yıldız vd. 1997) gibi özellikler rehberin mesleğe yönelik olumsuz duygusal durumlar beslemesine sebep olabilmektedir. Nitekim Köroğlu (2014) tarafından yapılan çalışmada turist rehberliği öğrencilerinin kişilik boyutları arasında "endişeye yatkınlık" boyutunda yüksek puan aldıkları belirlenmiştir. Ayrıca öğrencilerin mesleğe yönelik tutumları ile ilgili çalışmalar incelendiğinde meslekle ilgili en olumsuz görünen yönlerin mesleğin özellikleri ile tutarlı olduğu görülmektedir. Bunlar; işin doğası ve çalışma koşulları ve özel hayat boyutu, daha spesifik olarak ise çalışma saatlerinin uzunluğu, stresli çalışma ortamı ve işlerin yorucu olması, sürekliliği olmayan güvensiz bir iş ve çalışma saatlerinin düzenli bir hayat için uygunsuz olması olarak tespit edilmiştir (Tolga, Korkmaz ve Atay 2015). Buna ek olarak, turist rehberliği öğrencilerinin özellikle kriz dönemlerinde kariyer planlarını farklı alanlara yönelik tasarladıkları (Yetgin, Yılmaz ve Çiftçi 2018) ve sürekli kaygı düzeylerinin yüksek olduğu ortaya konmuştur (Halitoğulları ve Dinç 2018). 
Alanyazında, turizm rehberliği öğrencilerinin ve profesyonellerinin kaygıları, mesleğe yönelik tutumları ve profesyonellerin yeterlilikleri ile ilgili çalışmalar bulunmaktayken, turizm rehberliğinde mesleki kaygının nasıl boyutlandığı, bunun öğrencilerin öz-yeterlilikleri ve mesleği yapma veya kariyer niyetleri ile olan ilişkisi ile ilgili bir çalışma bulunmamaktadır. Buradan hareketle çalışma, alanyazındaki bu eksikliği gidermeyi öngörmektedir.

\section{YÖNTEM}

Araştırmanın evrenini, Adnan Menderes Üniversitesi Turizm Fakültesi, Balıkesir Üniversitesi Turizm Fakültesi, Nevşehir Hacı Bektaş Veli Üniversitesi Turizm Fakültesi ve Ege Üniversitesi Çeşme Turizm ve Otelcilik Yüksek Okulu Turizm Rehberliği bölümlerinde lisans düzeyinde öğrenim gören öğrenciler oluşturmaktadır. Araştırma evreni olarak seçilen üniversitelerin turizm rehberliği bölümlerinde öğrenim görmekte olan öğrenci sayısı 1669 olarak tespit edilmiştir. Bu bağlamda örneklem büyüklügü için 300-313 aralığı olarak uygun görülmektedir (Altunışık vd. 2012). Araştırmada örneklem seçimi olarak olasılığa dayalı olmayan örnekleme teknikleri içerisinden kolayda örnekleme yönteminin kullanılması tercih edilmiştir.

\section{Veri Toplama Araçları}

Mesleki Kaygı Ölçeği (MKÖ), Cabi ve Yalçınalp (2013) tarafından öğretmen adaylarına yönelik geliştirilen mesleki kaygı ölçeğinin turist rehberliği mesleğine uyarlanmasıdır. Genel ÖzYeterlilik Ölçeği Sherer vd. (1982) tarafından geliştirilen, Yıldırım ve İlhan (2010) tarafından Türkçeye uyarlanan Genel Öz-Yeterlilik Ölçeğidir. Mesleği Yapma Niyeti Ölçeği, Riegel ve Dallas (1998) ve Kuşluvan ve Kuşluvan (2003) tarafindan kullanilan, Duman, Tepeci ve Unur (2006) tarafından Türkçeye uyarlanan Turizmde Kariyer Yapma İsteği Ölçeğinin turist rehberliği mesleğine uyarlanmasıdır. Her üç ölçekte, 5'li Likert tipi dereceleme kullanılmıştır. Katılımcıların ölçekte bulunan soruları “1. Kesinlikle Katılmıyorum, 5. Kesinlikle Katılıyorum" arasındaki tepki kategorilerinden birini seçerek yanıtlamaları istenmiştir.
Araştırmada kullanılan öğretmen adaylarına yönelik Mesleki Kaygı Ölçeği ve Turizmde Kariyer Yapma İsteği Ölçeğinin maddeleri öncellikle araştırmacılar tarafından turist rehberliği mesleğine uyarlanmıştır. İlk uyarlamadan sonra her iki ölçek, araştırma modelinin açıklandığı bir formla beraber turist rehberliği alanında çalışan akademisyenlere uzman görüşü için gönderilmiştir. Uzman görüşünden sonra gelen düzeltmeler ve tavsiyeler bağlamında anket maddelerine ön test için son şekli verilmiştir.

\section{Ön Test ve Veri Toplama Süreci}

Ankette yer alan ölçeklerin ön testi için 18-29 Aralık 2017 tarihleri arasında Mersin Üniversitesi Turizm Fakültesi Turizm Rehberliği bölümünde öğrenim gören 110 öğrenciden veri toplanmıştır. İç tutarlılık göstergesi olan Cronbach Alfa istatistiği her ölçek için hesaplanmıştır. Elde edilen verilere göre ölçekler bazında güvenilirlik analizi sonuçları Tablo 1'de paylaşılmıştır.

Ölçeğin toplanabilirlik özelliğinin bozulmaması için soru ile bütün arasındaki korelasyon katsayılarının negatif olmaması ve ,250 değerinden büyük olması beklenir (Kalaycı 2016). Bu özelliğe uymadığı tespit edilen üç ifade analizden çıkarılmıştır. Her üç ölçeğin madde standart sapma değerlerinde çok yüksek veya çok düşük herhangi bir değer saptanmamıştır.

Anket uygulaması 1-31 Mart 2018 tarihleri arasında yapılmış ve kullanılabilir 537 anket elde edilmiştir. Her üç ölçekte çoklu sapan değere sahip olan toplam 63 gözlem veri setinden çıkarılmış ve analizler 474 gözlem üzerinden gerçekleştirilmiştir. Güvenirlik analizlerinde Cronbach Alfa Katsayısı göz önünde bulundurulmuştur. Daha sonra ölçek uyarlama işlemi yapılan “Mes-

Tablo 1. Ölçekler Bazında Pilot Araştırma Güvenilirlik Analizi Sonuçları

\begin{tabular}{lrrr}
\hline Ölçekler & $\begin{array}{r}\text { Madde } \\
\text { Sayısı }\end{array}$ & $\begin{array}{r}\text { Cronbach } \\
\text { Alfa Değeri }\end{array}$ & $\begin{array}{r}\text { Düzeltilmiş } \\
\text { Madde Toplam } \\
\text { Korelasyon Aralığı }\end{array}$ \\
\hline Mesleki Kaygı & 43 &, 943 &, $270-, 654$ \\
\hline Genel Öz-Yeterlilik & 16 &, 879 &, $297-, 700$ \\
\hline Mesleği Yapma Niyeti & 7 &, 793 &, $302-, 639$ \\
\hline
\end{tabular}


leki Kayg1" ve "Mesleği Yapma Niyeti" ölçeklerinin boyutlarını tespit etmek için ilgili değişkenlere faktör analizi uygulanmıştır. Son olarak değişkenler arasındaki ilişkileri belirlemek amacıyla korelasyon analizi uygulamaya alınmıştır.

\section{BULGULAR}

\section{Katılımcılara İlişkin Bilgiler}

Anket formunu yanıtlayan katılımciların yüzde 49,6'sı kadın, yüzde 50,4'ü erkektir. Araştırmaya katılanların yüzde 22,8'inin Ege Üniversitesi, yüzde 25,1'inin Adnan Menderes Üniversitesi, yüzde 32,1'inin Balıkesir Üniversitesi ve yüzde 20'sinin Nevşehir Hacı Bektaş Veli Üniversitesi'nde öğrenime devam etmektedir.

\section{Ölçeklere ilişkin Bulgular}

Ölçeklerin güvenirliğini tespit etmek için öncellikle Cronbach Alfa katsayıları dikkate alınarak Genel Öz-Yeterlilik, Mesleki Kaygı ve Mesleği Yapma Niyeti Ölçeklerine güvenirlik analizi uygulanmıştır. Değerlendirmeler ölçeğin ilk yarısı, ikinci yarısı ve ölçeğin tamamı için yapılmıştır. Bu kapsamda en büyük Alfa değerinin ,960 ve en küçük Alfa değerinin ,652 olduğu sonucu elde edilmiştir.

\section{Faktör Analizi}

Çalışmada Mesleki Kaygı Ölçeğinin KMO örneklem ölçümü ,945; Mesleği Yapma Niyeti Ölçeğinin $\mathrm{KMO}$ değeri ,812 olarak tespit edilmiştir. Bartlett Küresellik Testinin ( $\mathrm{p} \leq, 000)$ anlamlılık derecesinde Mesleki Kaygi Ölçeği için 10657,857

Tablo 2. Ölçeklerin Güvenirlik Analizlerine İlişkin Bulgular

\begin{tabular}{|c|c|c|c|}
\hline Alfa Katsayısı & $\begin{array}{l}\text { Ölçek öz } \\
\text { yeterlilik ölçeği } \\
\text { (16 madde) }\end{array}$ & $\begin{array}{l}\text { Mesleki Kaygı } \\
\text { i Ölçeği } \\
\text { (43 Madde) }\end{array}$ & $\begin{array}{r}\text { Mesleği } \\
\text { Yapma Niyeti } \\
\text { Ölçeği } \\
\text { (7 Madde) }\end{array}$ \\
\hline Ölçeğin ilk yarısı için & 0,911 & 0,930 & 0,850 \\
\hline Ölçeğin İkinci yarısı için & 0,710 & 0,933 & 0,652 \\
\hline Tüm ölçek verileri için & 0,876 & 0,960 & 0,853 \\
\hline $\begin{array}{l}\text { Negatif madde-toplam } \\
\text { korelasyonların varlığı }\end{array}$ & YOK & YOK & YOK \\
\hline \multicolumn{4}{|c|}{ Madde-toplam korelasyon } \\
\hline
\end{tabular}

ve Mesleği Yapma Niyeti Ölçeği için ise 1637,155 olduğu gözlenmektedir. Tablo 3, Mesleki Kayg1 Ölçeğine ilişkin faktör analizi sonuçlarını göstermektedir.

Mesleki Kayg 1 Ölçeği sekiz faktör altında toplanmış ve toplam varyansin yüzde $67,334^{\prime}$ ünü açıklamıştır. Elde edilen faktörler altında toplanan ifadelere göre sırasıyla; "İletişim ve İş Ortamı Merkezli Kayg1", "Görev Merkezli Kayg1", "İşsizlik ve Sınav Merkezli Kaygı", "İşveren ve Uyum Merkezli Kayg1", "Kişisel Gelişim Merkezli Kaygı", "Mesleki Gelişim Merkezli Kaygı", "Ekonomik Merkezli Kayg1", "Meslek Seçimi Merkezli Kaygı" şeklinde adlandırılmışlardır.

Mesleği Yapma Niyeti ölçeğinin faktör analizi sonuçları Tablo 4'te görülmektedir. Faktör analizi sonucunda, yedi ifadeden oluşan ölçeğin iki boyutta toplandığı bulunmuştur. Ölçeğin bütün olarak açıkladığı varyans oranı ise yüzde 69,246 olarak tespit edilmiştir. Beş ifadeden oluşan birinci faktör "Mesleğe Yönelik Olumsuz Yaklaşım" ve iki ifadeden oluşan ikinci faktör "Mesleğe Yönelik Olumlu Yaklaşım" olarak adlandırılmiştır.

Çalışmada turizm rehberliği öğrencilerinin öz-yeterlilik inançları, mesleki kaygı düzeyleri ve mesleği yapma niyetleri arasındaki ilişkinin derecesini ve yönünü test etmek amaciyla korelasyon analizinden yararlanılmıştır. Korelasyon analizi sonuçları Tablo 5 'te verilmiştir.

Tablo 5'te yapılan korelasyon analizi sonuçlarına göre turizm rehberliği öğrencilerinin özyeterlilik düzeyleri ile mesleki kaygı düzeyleri arasında istatistiksel olarak ters yönlü, anlamlı ve orta düzeyde bir ilişki saptanmıştır $(r=-0,480)$. Turizm rehberliği öğrencilerinin öz-yeterlilik düzeyleri ile mesleği yapma niyetleri arasında ise istatistiksel olarak pozitif yönlü, anlamlı ve orta düzeyde bir ilişki vardır ( $r=0,411)$. Diğer taraftan turizm rehberliği öğrencilerinin mesleki kaygı düzeyleri ile mesleği yapma niyetleri arasında istatistiksel olarak ters yönlü, anlamlı ve zayıf bir ilişki tespit edilmiştir ( $r=-0,332)$. Korelasyon analizi sonuçları göz önüne alındığında çalışmada oluşturulan üç hipotezin de kabul edildiği görülmektedir. 
Tablo 3. Mesleki Kaygı Ölçeğine İlişkin Faktör Analizi Sonuçları

\begin{tabular}{|c|c|c|c|c|c|}
\hline & Yük & Özdeğeri & A.Varyans & Ortalama & Alfa \\
\hline \multicolumn{4}{|l|}{ I. Iletişim ve Iş Ortamı Merkezli Kaygı (11 Madde) } & 2,5769 & 0,917 \\
\hline 25.Tur katılımcılarının beni sevmemesinden kaygılanırım. & 0,712 & & & 2,5318 & \\
\hline 23.Tur katılımcılarının sorunlarının farkına varamamaktan kaygılanırım. & 0,709 & & & 2,6583 & \\
\hline 24.Tur katılımcılarıyla empati kuramamaktan kaygılanırım. & 0,705 & & & 2,4398 & \\
\hline 26.Sorunlu tur katılımcıları ile başa çıkamamaktan kaygılanırım. & 0,675 & & & 2,7294 & \\
\hline 22.Tur katılımcılarından saygı görememekten kaygılanırım. & 0,647 & & & 2,7056 & \\
\hline 27.Meslektaşlarım ile iletişim kuramamaktan kaygılanırım. & 0,621 & 6,991 & 16,193 & 2,3672 & \\
\hline 30.Meslektaşlarımın alan bilgimi yetersiz bulmasından kaygılanırım. & 0,605 & & & 2,6554 & \\
\hline 21.Tur katılımcılarıyla iletişim kuramamaktan kaygılanırım. & 0,577 & & & 2,5340 & \\
\hline \multicolumn{6}{|l|}{ 28.Turda, tur katılımcıları, satış görevlileri veya meslektaşlarım } \\
\hline tarafından şiddete maruz kalmaktan kaygılanırım. & 0,576 & & & 2,3313 & \\
\hline 31.Seyahat acentalarının beni yetersiz bulmasından kaygılanırım. & 0,562 & & & 2,7779 & \\
\hline \multicolumn{6}{|l|}{ 29.Turda anlatım yaparken kontrol amaçlı (meslektaşlarım, acenta } \\
\hline yöneticileri vs. tarafından) izleniyor olmaktan kaygılanırım. & 0,510 & & & 2,6152 & \\
\hline \multicolumn{2}{|l|}{ II. Görev Merkezli Kaygı (9 Madde) } & 5,725 & 15,474 & 2,7106 & 0,917 \\
\hline 3.Tur katılımcılarının mesleki bilgimi yetersiz bulmasından kaygılanırım. & 0,759 & & & 2,8731 & \\
\hline 4.Katılımcıların tura ilgisini çekememekten kaygılanırım. & 0,753 & & & 2,7830 & \\
\hline \multicolumn{6}{|l|}{ 8.Tur sırasında bilgi ve becerilerimi tur katılımcılarına } \\
\hline aktaramamaktan kaygılanırım. & 0,750 & & & 2,7248 & \\
\hline 2.Bilgilerimi tur katılımcılarına aktaramamaktan kaygılanırım. & 0,712 & & & 2,6153 & \\
\hline \multicolumn{6}{|l|}{ 5.Tur katılımcıları bilemeyeceğim bir soruyu sorduğunda panik } \\
\hline yaşamaktan kaygılanırım. & 0,709 & & & 2,8745 & \\
\hline \multicolumn{6}{|l|}{ 10.Turlarda anlatım yöntem ve tekniklerini yerinde kullanamamaktan } \\
\hline kaygılanırım. & 0,677 & & & 2,6849 & \\
\hline 7.Tur öncesi, tura çıkacağım için huzursuzluk yaşamaktan kaygılanırım. & 0,661 & & & 2,6285 & \\
\hline \multicolumn{6}{|l|}{ 11.Tur programının uygulanmasını organize edememekten } \\
\hline kaygılanırım. & 0,552 & & & 2,6089 & \\
\hline \multicolumn{6}{|l|}{ 9.Bireysel farklılıkları göz önüne alarak anlatım yapamamaktan } \\
\hline kaygılanırım. & 0,540 & & & 2,6025 & \\
\hline III. İşsizlik ve Sınav Merkezli Kaygı (3 Madde) & & 2,620 & 7,081 & 3,1626 & 0,790 \\
\hline
\end{tabular}

37. Rehberlik ruhsatnamesini aldıktan sonra herhangi bir yerde iş

$\begin{array}{lll}\text { bulamamaktan kaygılanırım. } & 0,768 & 3,2321\end{array}$

38. Rehberlik ruhsatnamesini aldıktan sonra istediğim bir yerde

$\begin{array}{lll}\text { çalışamamaktan kaygılanırım. } & 0,754 & 3,3215\end{array}$

36.Turist Rehberliği için gereken sınavlardan (YDS vb.) başarısız

olmaktan kaygılanırım.

$\begin{array}{ll}0,587 & 2,9344\end{array}$

\begin{tabular}{|c|c|c|c|c|c|}
\hline IV. İşveren ve Uyum Merkezli Kaygı (4 Madde) & & 2,371 & 6,408 & 2,8245 & 0,765 \\
\hline \multicolumn{6}{|l|}{ 42.Seyahat acentalarının yönetimleri ile problem yaşamaktan } \\
\hline kaygılanırım. & 0,736 & & & 2,9409 & \\
\hline \multicolumn{6}{|l|}{ 43.Seyahat acentalarının yönetimlerinin bana adil } \\
\hline davranmamasından kaygılanırım. & 0,663 & & & 3,2459 & \\
\hline 40.İstemediğim bir bölgeye/şehre tura çıkmaktan kaygılanırım & 0,606 & & & 2,5859 & \\
\hline 41.Çalıştığım çevreye uyum sağlayamamaktan kaygılanırım. & 0,599 & & & 2,5254 & \\
\hline
\end{tabular}


Tablo 3. Mesleki Kaygı Ölçeğine İlişkin Faktör Analizi Sonuçları

\begin{tabular}{|c|c|c|c|c|c|}
\hline \multicolumn{2}{|l|}{ V. Kişisel Gelişim Merkezli Kaygı (3 Madde) } & \multirow[t]{2}{*}{2,199} & \multirow[t]{2}{*}{5,945} & \multirow{2}{*}{$\begin{array}{l}2,7021 \\
2,7384\end{array}$} & \multirow[t]{2}{*}{0,898} \\
\hline 33.Sıkıcı bir turist rehberi olmaktan kaygılanırım. & 0,765 & & & & \\
\hline 34.Tur grubuna iyi bir model olamamaktan kaygılanırım. & 0,755 & & & 2,6539 & \\
\hline \multicolumn{6}{|l|}{ 35.Benden beklenen mesleğimin gerektirdiği özellikleri } \\
\hline taşıyamamaktan kaygılanırım. & 0,616 & & & 2,7141 & \\
\hline \multicolumn{2}{|l|}{ VI. Mesleki Gelişim Merkezli Kaygı (3 Madde) } & 2,147 & 5,802 & 2,8605 & 0,745 \\
\hline \multicolumn{6}{|c|}{ 18.Mesleğimi yaptığım yerde sosyal ve kültürel faaliyetlerin kısıtlı } \\
\hline olmasından kaygılanırım. & 0,803 & & & 2,9513 & \\
\hline \multicolumn{6}{|l|}{ 19.Turlarda çalışma ortamının (tur otobüsü vb.) mesleğimi } \\
\hline yapmaya uygun olmamasından kaygılanırım. & 0,770 & & & 2,9155 & \\
\hline \multicolumn{6}{|l|}{ 17.Mesleğimde kendimi geliştireceğim olanakları } \\
\hline bulamamaktan kaygılanırım. & 0,607 & & & 2,7149 & \\
\hline \multicolumn{2}{|l|}{ VII. Ekonomik Merkezli Kaygı (2 Madde) } & 2,033 & 5,494 & 2,7984 & 0,866 \\
\hline \multicolumn{6}{|l|}{ 14.Mesleğimden elde edeceğim gelirin standart bir yaşam için } \\
\hline yeterli olamayacağımdan kaygılanırım. & 0,815 & & & 2,8415 & \\
\hline \multicolumn{6}{|l|}{ 15.Mesleğimden elde edeceğim gelir ile ailemin ihtiyaçlarını } \\
\hline karşılayamamaktan kaygılanırım. & 0,780 & & & 2,7553 & \\
\hline \multicolumn{2}{|l|}{ VIII. Meslek Seçimi Merkezli Kaygı (2 Madde) } & 1,827 & 4,939 & 2,7846 & 0,675 \\
\hline 1.Rehberlik mesleğini seçmekte kararsızlık yaşamaktan kã & 0,727 & & & 2,7992 & \\
\hline \multicolumn{4}{|c|}{ 39.Rehberlik mesleğini seçtiğimden dolayı pişman olmaktan kaygılanırım0,649 } & 2,7700 & \\
\hline
\end{tabular}

Varimax rotasyonlu temel bileşenler analizi. Açılkanan toplam varyans: Yüzde 67,334

KMO örneklem yeterliliği: Yüzde 94,5; Bartlett's küresellik testi: $x^{2}: 10657,857$, s.d.:666, p<0,0001;

Genel ortalama: 2,7406; Ölçeğin tamamı için Alpha: 0,955;

Yanıt kategorileri: 1: Kesinlikle Katılmıyorum...5: Kesinlikle Katılıyorum

Tablo 4. Mesleği Yapma Niyetine İlişkin Faktör Analizi Sonuçları

\begin{tabular}{|c|c|c|c|c|c|}
\hline & Yük & Özdeğeri & A.Varyans & Ortalama & Alfa \\
\hline Mesleğe Yönelik Olumsuz Yaklaşım (5 Madde) & & 3,796 & 54,232 & 3,4902 & 0,876 \\
\hline 1.Mezun olunca turist rehberliği yapacağımı sanmıyorum & 0,850 & & & 3,3017 & \\
\hline 2.Bu meslekte uzun yıllar çalışacağımı düşünmüyorum & 0,844 & & & 3,1353 & \\
\hline 5.Turist Rehberliğini seçmem benim için bir hata idi. & 0,773 & & & 3,7932 & \\
\hline 3.Okuldan mezun olunca ne iş yapacağımı bilmiyorum. & 0,747 & & & 3,4080 & \\
\hline $\begin{array}{l}\text { 4.Turist rehberliğinde kariyer yapmanın bana kazandıracağı } \\
\text { fazla bir şey yok. }\end{array}$ & 0,745 & & & 3,8132 & \\
\hline Mesleğe Yönelik Olumlu Yaklaşım (2 Madde) & & 1,051 & 15,014 & 3,2653 & 0,646 \\
\hline $\begin{array}{l}\text { 6.Turist rehberliğine yönelik iş olanakları ile ilgileniyorum. } \\
\text { 7.Genellikle arkadaşlarla turist rehberliğine yönelik iş olanakları }\end{array}$ & 0,840 & & & 3,4123 & \\
\hline hakkında olumlu konuşuruz. & 0,828 & & & 3,1184 & \\
\hline
\end{tabular}

Varimax rotasyonlu temel bileşenler analizi. Açıklanan toplam varyans: Yüzde 69,246

KMO örneklem yeterliliği: Yüzde 81,2; Bartlett's küresellik testi: $x^{2}$ : 1637,155, s.d.:21, p<0,0001;

Genel ortalama: 3,4260; Ölçeğin tamamı için Alpha: 0,853;

Yanıt kategorileri: 1:Kesinlikle Katılmıyorum...5:Kesinlikle Katılıyorum 
Tablo 5. Turizm Rehberliği Öğrencilerinin Öz-yeterlilik İnançları, Mesleki Kaygı Düzeyleri ve Mesleği Yapma Niyetleri Arasındaki Korelasyon Analizi

\begin{tabular}{lrr}
\hline Değişken & 1 & 2 \\
\hline 1 Öz-yeterlilik & - & - \\
\hline 2 Mesleki Kaygı &,$- 480^{* *}$ & - \\
\hline 3 Mesleği Yapma Niyeti &, $411^{* *}$ &,$- 332^{* *}$ \\
\hline$* * p<0.01$ & &
\end{tabular}

\section{SONUÇ VE ÖNERILER}

Öncelikli olarak, turizm rehberliği bölümü öğrencilerinin mesleki kaygı düzeyleri istatistiksel olarak orta düzeye yakındır ve öğrenciler mesleki kaygılarını sekiz boyutta algılamaktadırlar. Bu sonuç farklı alanlarda yapılan çalışmalarla tutarlıdır (Cabi ve Yalçınalp 2013). Diğer taraftan turizm rehberliği öğrencilerinin 'işsizlik ve sinav merkezli kaygı'larının en yüksek ortalamaya sahip olduğu görülmektedir. Bunu sırasıyla; 'mesleki gelişim merkezli kaygi' ve 'işveren ve uyum merkezli kaygi' faktörleri takip etmektedir. Bu bağlamda turizm rehberliği öğrencilerinin özellikle mezuniyet sonrası iş bulamamaktan ve mesleğe giriş için gerekli olan sınavlardan başarısız olmaktan kaygılandıkları söylenebilir. Benzer şekilde öğrencilerin turist rehberliği mesleğini yapma niyetlerinin istatistiksel olarak orta düzeye yakın olduğu görülmektedir. Diğer taraftan turizm rehberliği öğrencileri turist rehberliği mesleğini yapma niyetlerini iki boyutta algilamaktadırlar ve mesleğe yönelik olumsuz yaklaşımları daha baskındır.

Turizm rehberliği öğrencilerinin öz-yeterlilik inançları ile mesleki kaygı düzeyleri arasında istatistiksel olarak ters yönlü ve anlamlı bir ilişki saptanmıştır. Bu sonuç farklı alanlarda yapılan çalışmamalarla tutarlılık göstermektedir (Kafkas vd. 2010). Bu bağlamda bireyin öz-yeterlilik inancı yükseldikçe algıladığı mesleki kaygının azaldığı görülmektedir. Diğer taraftan mesleki kayg1 ile mesleği yapma niyeti arasında istatistiksel olarak ters yönlü ve anlamlı bir ilişki tespit edilmiştir. Bu sonuç, kaygının davranışsal etkilerinde belirtilen engelleyici etki olarak yorumlanabilir. Eğer birey bir görev veya eylemin kendi becerilerini aştığını hissederse bu durumda kay- gının engelleyici etkisi ortaya çıkmaktadır (Scovel 1978). Bu bağlamda turizm rehberliği öğrencilerinin mesleğin kendi becerilerini aştıklarını algıladıkları söylenebilir. Buna ek olarak turizm rehberliği öğrencilerinin genel öz-yeterlilik düzeyleri ile mesleği yapma niyetleri arasında istatistiksel olarak pozitif yönlü ve anlamlı bir ilişki olduğu belirlenmiştir. Turizm rehberliği öğrencilerini mesleki kaygı düzeyleri düştükçe ve özyeterlilik düzeyleri yükseldikçe mesleği yapma niyetlerini arttı̆̆ görülmektedir.

Çalışma, turizm ve turist rehberliği alanyazınına mesleki kaygı kavramını kazandırarak, özellikle turizm rehberliği öğrencilerinin mesleğe daha iyi hazır edilebilmesi için çıktılar sunmaktadır. Elde edilen sonuçlardan hareketle, eğitim kurumlarının turist rehberi adaylarının mesleği başarıyla yapabileceklerine olan inançlarını arttırabilen ve mesleki kaygılarını azaltabilen eğitim çalışmalarına yer verilmesi önerilebilir. Örneğin; uygulamaya yönelik derslere daha fazla ağırlık verilebilir ve profesyonel turist rehberleri ile düzenli olarak söyleşiler düzenlenebilir. Ayrıca turist rehberi adaylarına mesleği daha yakından tanıyabilmeleri adına seyahat acentelerinde ve tur operatörlerinde staj yapma ve profesyonel bir turist rehberinin yanında yardımcı rehber olarak çalışması olanağı sağlanması önerilebilir.

Turist Rehberleri Birliği (TUREB) ve kendisine bağlı turist rehberleri odalarının turizm rehberliği alanında eğitim faaliyeti yürütmekte olan tüm yükseköğrenim kurumlarıyla özellikle ders müfredatlarının turist rehberliği mesleğine uygun hazırlanması konusunda koordinasyon içinde hareket etmeleri önerilebilir. Ayrıca rehber adaylarının işsizlik merkezli kaygılarının yüksekliği dikkate alındığında meslek örgütlerinin yeni başlayan rehberlere iş bulma konusunda yardım$\mathrm{C}$ olmaları ve buna yönelik olarak bir sistem tasarlamaları tavsiye edilebilir.

Çalışmada, mesleki kaygının diğer değişkenlerle ilişkisine bakılmıştır, bu bağlamda sonraki çalışmalarda mesleki kaygıya etki eden değişkenler, örneğin güvencesizlik ve risk algısı gibi, sınanabilir. Ayrıca, turizm rehberliği eğitimi vermekte olan diğer üniversitelerde önlisans ve lisansüstü eğitim görmekte olan öğrenciler 
dâhil edilip farklılıklar incelenebilir. İleriki yıllarda yapılacak araştırmalar için bir diğer öneri ise turizm rehberliği mesleğine özgü bir mesleki öz-yeterlilik ölçeğinin geliştirilmesi ve diğer değişkenlerle olan ilişkinin incelenmesidir. Bu çalışmada turizm rehberliği mesleği bir kariyer alanı olarak değil, bir meslek alanı olarak ele alınmıştır. Buradan hareketle, ilerde yapılacak çalışmalarda turizm rehberliği öğrencilerin turist rehberliği mesleğini bir kariyer alanı olarak nasıl algıladıkları ve öz-yeterlilik, mesleki kaygı ve diğer değişkenler ile olan ilişkisi incelenebilir. Son olarak, turizm fakültelerinin diğer bölümlerinde eğitim alan öğrencilerin de mesleki kaygıları incelenip benzer veya farklı değişkenlerle olan ilişkisi araştırılabilir.

\section{KAYNAKÇA}

Abele, A. ve Spurk, D. (2009). The Longitudinal Impact of Self-Efficacy and Career Goals on Objective and Subjective Career Success, Journal of Vocational Behavior, 74(1): 53-62.

Ahipaşaoğlu, S. (2006). Turizmde Rehberlik. Ankara: Gazi Kitabevi.

Aşkar, P. ve Umay, A. (2001). İlköğretim Matematik Öğretmenliği Öğrencilerinin Bilgisayarla İlgili Öz Yeterlilik Alg1s1, Hacettepe Üniversitesi Eğitim Fakültesi Dergisi, 21: 1-8.

Altunışık, R., Coşkun, R., Bayraktaroğlu, S., Yıldırım, E. (2012). Sosyal Bilimlerde Araştırma Yöntemleri (SPSS uygulamall). Sakarya: Sakarya Yayıncilı.

Bandura, A. (1982). Self-Efficacy Mechanism in Human Agency, Amercian Psycholgist, 37(2): 122-147.

Bandura, A. (1994). Self-efficacy. İçinde V. S. Ramachaudran (Editör), Encyclopedia of Human Behavior (ss. 71-81). New York: Academic Press.

Betz, N. ve Hackett, G. (1981). The Relationship of CareerRelated Self-Efficacy Expectations to Perceived Career Options in College Women and Men, Journal of Counseling Psychology, 28(5): 399-410.

Cabi, E. ve Yalçınalp, S. (2013). Öğretmen Adaylarına Yönelik Mesleki Kaygi Ölçeği (MKÖ): Geçerlik ve Güvenirlik Çalışması, Hacettepe Üniversitesi Eğitim Fakültesi Dergisi, 44(2013): 85-96.

Chesnut, S. R. ve Burley, H. (2015). Self-efficacy as a Predictor of Commitment to The Teaching Profession: A metaanalysis, Educational Research Review, 15: 1-16.

Çakmak, Ö. ve Hevedanll, M. (2005). Eğitim ve Fen-Edebiyat Fakülteleri Biyoloji Bölümü Öğrencilerinin Kaygı Düzeylerinin Çeşitli Değişkenler Açısından İncelenmesi, Elektronik Sosyal Bilimler Dergisi, 5(14): 115-127.

Deer, L. B., Gohn, K., Kanaya, T. (2018). Anxiety and Selfefficacy as Sequential Mediators in US College Students' Career Preparation, Education + Training, 60(2): 185-197.
Değirmencioğlu, A. Ö. (2001). Türkiye'de Turizm Rehberliği Üzerine Bir Araştırma, Anatolia: Turizm Araştırmaları Dergisi, 12(2): 189-196.

Doğan, H., Üngüren, E., Dönmez Kesgin, D. (2010). Meslek ve Aile Yaşamı İlişkisi: Profesyonel Turist Rehberlerine Yönelik Bir Araştırma, Journal of Yasar University, 20(5): 3430-3442.

Duman, T., Tepeci, M., Unur, K. (2006). Mersin'de Lisans, Ön Lisans ve Lise Düzeyinde Turizm Eğitimi Almakta Olan Öğrencilerin Sektörün Çalışma Koşullarını Algılamaları ve Sektörde Çalışma İsteklerinin Karşılaştırmalı Analizi, Anatolia: Turizm Araştırmaları Dergisi, 17(1): 51-69.

Ergin, A., Uzun, S. U., Topaloğlu, S. (2016). Pamukkale Üniversitesi Tıp Fakültesi 5. ve 6. Sınıf Öğrencilerinin Sürekli Kaygı ve Mesleki Kaygı Düzeyleri ve Bunları Etkileyen Etkenler, Muğla Sıtkı Koçman Üniversitesi Tıp Dergisi, 3(3): 16-21.

Everhart, C. ve Chelladurai, P. (1998). Gender Differences in Preferences for Coaching as an Occupation: The Role of Self-Efficacy, Valence, and Perceived Barriers, Research Quarterly for Exercise and Sport, 69(2): 188-200.

Güzel, F. Ö., Türker, A., Şahin, İ. (2014). Profesyonel Turist Rehberlerinin Algıladıkları Mesleki Engelleri Belirlemeye Yönelik Bir Araştırma, Gazi Üniversitesi Turizm Fakültesi Dergisi, 2: 173-190.

Halitoğulları, H. ve Tetik Dinç, N. (2018). Turizm Rehberliği Öğrencilerinin Sürekli Kayg1 Düzeylerinin Belirlenmesi. İçinde N. Hacıoğlu, C. Avcıkurt, A. Kılıç ve H. Ulusoy Yıldırım (Editörler), Turist Rehberliği Üzerine Güncel Araştırmalar (ss. 523-534). Ankara: Detay Yanyıncıllk.

İrigüler, F. ve Güler, M. E. (2016). Emotional Labor Of Tourist Guides: How Does It Affect Their Job Satisfaction And Burnout Levels, Journal of Yasar University, 11 (42): 113-123.

Kafkas, M., Açak, M., Çoban, B., Karademir, T. (2010). Beden Ĕgitimi Öğretmen Adaylarının Öz-Yeterlik Algıları ile Mesleki Kaygıları Arasındaki İlişki, İпönü Üniversitesi Eğitim Fakültesi Dergisi, 11(2): 93-111.

Kalaycı, Ş. (2016). SPSS Uygulamalı Çok Değişkenli İstatistik Teknikleri. Ankara: Asil Yayıncllı.

Kimes, H. G. ve Troth, W. A. (1974). Relationship of Trait Anxiety to Career Decisiveness, Journal of Counseling Psychology, 21(4): 277-28.

Köroğlu, Ö. (2014), Meslek Seçimi ile Kișilik Özellikleri Arasındaki İlişskinin Belirlenmesi: Turizm Rehberliği Öğrencileri Bir Araştırma, Süleyman Demirel Üniversitesi İktisadi ve İdari Bilimler Fakültesi Dergisi, 19(2): 137-157.

Kuşluvan, S. ve Kuşluvan, Z. (2003). Perceptions and Attitudes of Undergraduate Tourism Students Towards Working in the Tourism and Hospitality Industry in a Developing Economy. İçinde S. Kuşluvan (Editör), Managing Employee Attitudes and Behaviors in the Tourism and Hospitality Industry. (ss. 77-98), New York: Nova Science Publishers Inc.

May, R. (1950). The Meaning of Anxiiety. New York: Ronald Press.

Nevill, D. ve Schlecker, D. (1988). The Relation of Self-Efficacy and Assertiveness to Willingness to Engage in Traditional/Nontraditional Career Activities, Psychology of Women Quarterly, 12(1): 91-98. 
Pajares, F. ve Miller, D. M. (1994). Role of Self-Efficacy and Self-Concept Beliefs in Mathematics Problem Solving: A Path Analysis, Journal of Educational Psychology, 86(2): 193-203.

Riegel, C. ve Dallas, M. (1998). Hospitality and Tourism Careers: A Blue Print For Success. New Jersey: Prentice Hall Inc.

Scovel, T. (1978). The Effect of Affect on Foreign Language Learning: A Review of The Anxiety Research, Lenguage Learning, 28(1): 129-142.

Serin, M. K., Güneş, A. M., Değirmenci, H. (2015). Sınıf Öğretmenliği Bölümü Öğrencilerinin Öğretmenlik Mesleğine Yönelik Tutumları ile Mesleğe Yönelik Kaygı Düzeyleri Arasındaki İlişki, Cumhuriyet International Journal of Education, 4(1): 21-34.

Sherer, M., Maddux, J. E., Mercandante, B., Prentice-Dunn, S., Jacobs, B. ve Rogers, R. W. (1982). The Self- Efficacy Scale: Construction and Validation, Psychological Reports, 51(2): 663-671.

Spielberger, C. D. (1966). Theory and Research on Anxiety and Behavior. New York: Academic Press.

Tetik, N. (2006). Türkiye'de Profesyonel Turist Rehberliği ve Müşterilerin Turist Rehberlerinden Beklentilerinin Analizi (Kuşadası örneği). (Basılmamış Yüksek Lisans Tezi). Balıkesir: Balıkesir Üniversitesi, Turizm İşletmeciliği Ana Bilim Dalı.
Tolga. Ö., Korkmaz, H., Atay, L. (2015). Lisans Düzeyindeki Turist Rehberliği Öğrencilerinin Mesleki Tutumlarına Yönelik Bir Araştırma, Seyahat ve Otel İşletmeciliği Dergisi, 12(2): 26-41.

Weiler, B. ve Black, R. (2015). Tour Guiding Research: Insights, Issues and Implications. Bristol: Channel View Publications.

Yazıcıoğlu, İ., Tokmak, C. ve Uzun, S. (2008). Turist Rehberlerinin Rehberlik Mesleğine Bakışı, Üniversite ve Toplum, 8(2): 1-19.

Yetgin, D. (2017). Turist Rehberlerinin Tükenmişlik ve Ekonomik Kaygı Düzeylerinin Mesleki Bağlılık Düzeyleri Üzerindeki Etkisi. (Basılmamış Doktora Tezi). Eskişehir: Anadolu Üniversitesi, Turizm İşletmeciliği Ana Bilim Dalı.

Yetgin, D., Yılmaz A. ve Çiftçi, G. (2018). Krizlerin Turist Rehberliği Öğrencilerinin Kariyer Planlamasındaki Etkisi, Journal of Tourism and Gastronomy Studies, 6(3): 195-214.

Yıldırım, F. ve İlhan, İ. Ö. (2010). Genel Özyeterlilik Ölçeği Türkçe Formunun Geçerlilik ve Güvenilirlik Çalışması, Türk Psikiyatri Dergisi, 21(4): 301-308.

Yıldız, R., Kuşluvan, S., Şenyurt, Y. (1997). Türkiye'de turizmin gelişmesinde turist rehberlerinin rolü (Turist rehberliği öğretiminde yeni bir model: Nevşehir turist rehberliği bölümü programı ve değerlendirmesi), Hafta Sonu Semineri IV. (ss. 7-36). Nevşehir: Nevşehir Üniversitesi Yayınları.

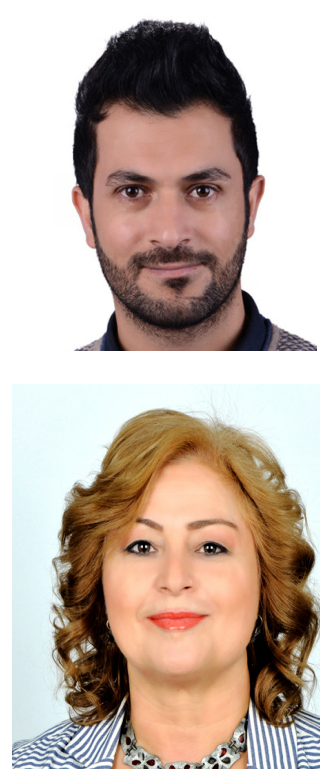

Burhan ÇINAR

Ege Üniversitesi Çeşme Turizm ve Otelcilik Yüksekokulu Turizm Rehberliği Bölümü'nden mezun oldu (2014). Yüksek lisans derecesini Mersin Üniversitesi'nden Turizm Rehberliği Ana Bilim Dalı'ndan aldı (2018). Doktora eğitimine Mersin Üniversitesi Turizm İşletmeciliği Ana Bilim Dalı’nda devam etmektedir. Mersin Üniversitesi'nde Araştırma Görevlisi olarak çaıışmaya başladı (2016). Temel çalışma alanı, turist rehberliğidir.

\section{Uysal YENIPINAR}

Çukurova Üniversitesi iktisadi ve İdari Bilimler Fakültesi'nden mezun oldu (1983). Yüksek lisans derecesini Hacettepe Üniversitesi'nden İşletme Ana Bilim Dalı́ndan (1987), doktora derecesini de Dokuz Eylül Üniversitesi'nden Turizm İşletmeciliği Ana Bilim Dalı'ndan aldı (2004). Turizm Bakanlığı bursu ile İngiltere'de "Turizmde Halkla Illişkiler" eğitimi aldı (1991). Turizm Bakanlığı Tanıtma Genel Müdürlüğü’nde çalıştı (1993). Mersin Üniversitesi Gülnar Meslek Yüksekokulu'nda öğretim görevlisi olarak çalışmaya başladı (1997). Ardından Ege Üniversitesi Çeşme Turizm ve Otelcilik Yüksekokulu'nda çalıştı (2003). Sonrasında Mersin Üniversitesi Turizm Fakültesi'nde çalışmaya başladı (2013). Mersin Üniversitesi Turizm Fakültesi Turizm Rehberliği Bölüm Başkanlığı'na atandı (2015). Doçentlik unvanını Turizm İşletmeciliği alanında aldı (2017). Halen Mersin Üniversitesi Turizm Fakültesi'nde görev yapmaktadır. Temel çalışma alanları, destinasyon yönetimi, pazarlama ve turist rehberliğidir. 